\title{
Social innovations as a basis for sustainable development of the industrial region
}

\author{
Anna Kisova ${ }^{1, *}$ and Kristina Barsukova ${ }^{1}$ \\ ${ }^{1}$ Lipetsk State Technical University, Lipetsk, Russia
}

\begin{abstract}
The aim of the work is to study the relationship between the sustainable development of an industrial region and social innovations. The paper highlights its features high-quality economic growth, the pace of socio-economic development, lean manufacturing, the introduction of high technologies, ensuring economic security, social innovations, considering the studied theoretical ideas about the essence and content of sustainable development of the industrial region. The author's interpretation of the economic content of the concept of "social innovations» is justified. They represent qualitative changes in the areas of continuous reproduction of human and social capital to eliminate contradictions in economic interests and improve personal and public well-being. The features of social innovations (anthropocentrism, strategic nature, inertia, specificity, synergy, creativity, high degree of risk), reflecting their qualitative certainty, are revealed. The author argues that social innovations are a multi-faceted and rather complex economic category, the content of which should be considered through its types and forms of implementation. Using the example of an industrial region, the Lipetsk region, the authors studied such types of social innovations as the social contract and social entrepreneurship. As a result of the research, it is established that the social contract can be one of the sources of social entrepreneurship, which in turn determines the reproductive function of social innovations. Also, social innovations are an effective tool for improving the level of personal and public well-being by reducing contradictions in society and reducing social tension.
\end{abstract}

\section{Introduction}

Sustainable development of the region, including industrial development, is a balance between the level of tangible and intangible benefits and the functioning of economic entities [1-12], that is, "the ability of the economy to develop near a long-term trend" [13].

It is characterized by the following features:

- First, its statistical and dynamic state is determined not by the growth rate, but by the pace of socio-economic development [6].

- Secondly, the dominant role is played by the qualitative (inclusive), rather than quantitative, type of economic growth,

\footnotetext{
* Corresponding author: zaumka84@mail.ru
} 
- Third, there must be such components as lean manufacturing, the introduction of high technologies, and ensuring economic security,

- Fourth, sustainable development implies the mandatory introduction of innovations in all spheres of human life, since they ensure the achievement of continuous and high-quality reproduction of human and social capital, and therefore are one of the factors for achieving a balanced development of the socio-economic system of the territory (region); "...human capital is an important factor in economic development..." [11].

Thus, the basis of sustainable urban development is based on three fundamental components: economic growth, environmental management, and the involvement of residents in solving social issues (Derlukiewicz \& Mempel-Sniezyk, 2018). Sustainable development of these elements, in our opinion, should also be accompanied by the presence of innovations, in particular, social ones, "since they imply qualitative changes in all its factors and results" [9].

\section{Materials and Methods}

The methodological basis of the scientific research is the concept of sustainable development of industrial territories in the relationship of such categories as social innovation, its main types and forms. To substantiate the results of the study, a set of scientific approaches was used: historical-genetic, system, project, institutional, and structural. The paper uses techniques and methods of formal and dialectical logic (analysis and synthesis, comparisons, analogies, unity of historical and logical).

The research is based on monographs, materials of periodicals, scientific articles made on the studied problems.

\section{Results and Discussion}

Social innovation is a prerequisite for sustainable development. The analysis of the scientific literature on this issue has shown that today there is no clear definition of social innovation, different authors interpret this category from different positions. Within the framework of this article, social innovations will be understood as transformational changes in the areas of formation and development of human and social capital to eliminate contradictions in the interests and increase personal and public well-being.

Note that the qualitative certainty of social innovations is due to several their characteristic features:

- First, the peculiarity of social innovation is anthropocentrism, i.e., the study of economic processes in the human dimension: the economy and technology are the means, and the person, his material, physical, and moral well - being are the main social indicators of the progressiveness or regressiveness of the policy. "Man stands at the center of the socioeconomic system as a producer and consumer" [1],

- Secondly, the strategic nature. The creation and implementation of social innovations is a key factor in the transformation of the socio-economic system in the long term, which leads to sustainable development,

- Third, the inertia. Innovation inertia of the socio-economic system is any actions of its subjects aimed at delaying or countering the implementation of innovations in the organization,

- Fourth, the specificity. Social innovations serve as a tool for complex, but at the same time exclusively situational (based on the prevailing external conditions) solutions to global problems, starting with small groups and ending with large-scale changes [12], 
- Fifth, the synergies. The introduction of social innovations can be accompanied by the emergence of a synergy effect due to the interaction of economic entities,

- Sixth, creativity. The creation of social innovation is necessarily accompanied by such phenomena as creativity and creative approach. Without these two components, its occurrence is impossible,

- Seventh, a high degree of risk. Social innovations by their nature are characterized by a higher level of risk than, for example, technological ones, since their formation, dissemination and implementation in practice depends on the quality of social capital in a particular system.

Consequently, social innovations are a multi-faceted and rather complex economic category, the content of which can be considered through its types and forms of implementation.

It should be noted that according to the "Strategy of Innovative Development of the Russian Federation for the period up to 2020", the introduction of social innovations will significantly improve the quality of services provided to the population, reduce the time of their provision, provide feedback on the control of timeliness and quality, as well as increase their availability.

According to Figure 1, it can be noted that there is a high differentiation of the income of the population in Russia.

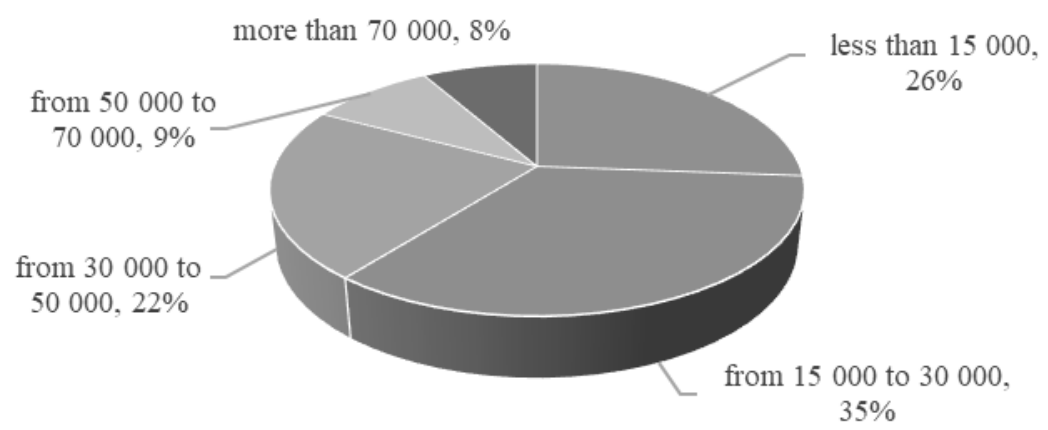

Fig. 1. Distribution of income of the Russian population by groups, \%.

The first two indicators in total - income up to 15 thousand rubles and from 15 to 30 thousand rubles, we will see that $60 \%$ of the population of Russia have a monetary income of less than 30 thousand rubles per month.

To reduce the differences in the income of the population, the state authorities have resorted to such a type of social innovation as the social contract. It is worth explaining that a social contract is a contract that is concluded between a poor family and the social protection authorities of the population. The social contract in Russia, according to the statement of the President of the Russian Federation V. V. Putin, is focused on supporting each "individual person in need". According to this contract, a person is not a passive subject of social assistance, he must take active actions together with state authorities to overcome a difficult life situation, which is defined according to the law as a circumstance or circumstances that worsen the living conditions of a citizen and the consequences of which he cannot overcome independently.

In addition, the analysis of the concept of "social contract" in the conditions of the Russian economy allows us to note that:

- only low-income families can conclude a social contract. In this case, it can be either a single married couple, or a family with one or more children, as well as families with disabilities, pensioners, etc. All family members must be registered in one place. Those 
who are registered at a different address will not be considered when calculating the average family income. The category of the poor includes those citizens whose income is less than the subsistence minimum established in the region. The calculation considers all income, including student scholarships, pensions, and surcharges,

- to obtain this support, the family can only be a once in a lifetime. It is concluded for a period of three months to one year. The amount of monthly payments varies from 5 to 60 thousand per month and is calculated individually for each family, depending on its position and capabilities,

- the main activities within the framework of the social contract are job search, training, implementation of individual entrepreneurship activities, maintenance of a subsidiary farm;

- the expected results of the application of social contract are the implementation of labor potential recipients of state social assistance; raising the standard of living of poor people at the expense of regular independent sources of income in cash or in kind; social rehabilitation of the members of poor families; strengthening the social responsibility of recipients, reducing dependency motive for their behavior,

- the tactical purpose of this agreement is to encourage active actions of applicants to overcome a difficult life situation; and the basis for concluding a social contract is the presence of a difficult financial situation in the family, i.e. the presence of an average per capita income less than the minimum wage. The strategic goal of the state, provided that the mechanism of the social contract is used, is to increase the level of personal well-being, increase labor productivity through the growth of human capital.

According to the presented data, we can see that the social contract is not a one-time material payment, but a tool for improving a person's personal well-being through the continuous reproduction of private capital obtained with the help of state social support institutions at the federal level. The allocated funds are targeted and can only be spent on the directions prescribed in the law.

For example, with the allocated funds, you can buy equipment, make repairs and complete the necessary premises, buy tools, and undergo a course of treatment. It should be considered that when a family enters a social contract, it does not lose its rights to other types of assistance from the state [3].

The main principles of providing state social assistance to people through a social contract are:

- voluntary participation,

- the obligation to fill the terms of the social contract,

- individual approach in determining the terms of the social contract,

- the targeted nature of assistance.

In the Lipetsk region in 2020, funds were allocated from the federal budget in the amount of 424,2 million rubles for the implementation of measures aimed at providing a social contract, from the regional budget - 165 million rubles, from the consolidated budget for the implementation of these measures $-589,3$ million rubles.

The social contract is one of the sources of social entrepreneurship development. We can say that one type of social innovation is transformed into another.

The term "social entrepreneurship" is relatively new to Russian practice and allows for a broad interpretation. In the Russian scientific literature, social entrepreneurship is understood as the activity of non-profit organizations, whose income from entrepreneurial activity is used for legal purposes [10].

According to the Federal Law of the Russian Federation No. 245-FZ of July 26, 2019, social entrepreneurship is an entrepreneurial activity aimed at achieving socially useful goals, contributing to the solution of social problems of citizens and society, and carried out in accordance with the conditions. 
Researchers and experts of the Fund for Regional Social Programs "Our Future" have formulated their own version of the definition of social entrepreneurship: "social entrepreneurship is an entrepreneurial activity aimed at mitigating or solving social problems, characterized by the following characteristics: social impact, innovation, selfsufficiency, scale, replication. It combines a social focus and an entrepreneurial approach, is at the intersection of entrepreneurship and charity, and involves the creation of a social good not through pure charity, but through profitable or partially profitable activities."

Based on these definitions, it becomes clear that the main goal of social enterprises is to solve social problems by innovative methods, i.e., to create a social good through the implementation of entrepreneurial activities.

Subjects of social entrepreneurship in Russia can be:

1) enterprises that specialize in the production of products or the provision of services for the benefit of socially vulnerable and low-income groups of citizens or create jobs for them; 2) the subjects of small and medium-sized enterprises, whose activities are aimed at:

- providing employment and support to the disabled, the elderly and people in difficult life situations,

- improving the living conditions of citizens,

- expanding the ability of citizens to meet their basic living needs.

The provision of support to social enterprises can be carried out in the form of:

1) ensuring the availability of infrastructure to support social enterprises,

2) providing financial support to social enterprises (including through the provision of subsidies),

3) providing property support to social enterprises (including by providing ownership and (or) use of state and municipal property on preferential terms),

4) providing information support to social enterprises,

5) providing consulting and methodological support to social enterprises (including on issues of attracting financing and participation in the procurement of goods, works, and services),

6) assistance in the development of interregional cooperation, search for business partners, including by holding fairs, business congresses, exhibitions, as well as ensuring the participation of social enterprises in these events in the territories of the subjects of the Russian Federation and in the territories of municipalities,

7) organization of professional training, basic professional education, additional professional education and assistance in passing an independent assessment of the qualifications of employees of social enterprises in accordance with the legislation of the Russian Federation,

8) implementation of other measures (measures) to support social enterprises that are provided for by federal laws, other regulatory legal acts of the Russian Federation adopted in accordance with them, as well as laws and other regulatory legal acts of the subjects of the Russian Federation, municipal legal acts.

According to the order of the Ministry of Economic Development of the Russian Federation No. 167, the categories of citizens whose employment is recognized as social entrepreneurship include:

- disabled people,

- orphans and graduates of orphanages,

- women with children under 7 years of age,

- elderly citizens,

- persons in a difficult life situation,

- released from places of deprivation of liberty for up to 2 years ago. 
A social enterprise is an organization in which the share of employees represented in these categories must be at least 50\%, and their share in the wage fund at least $25 \%$ (Figure 2).

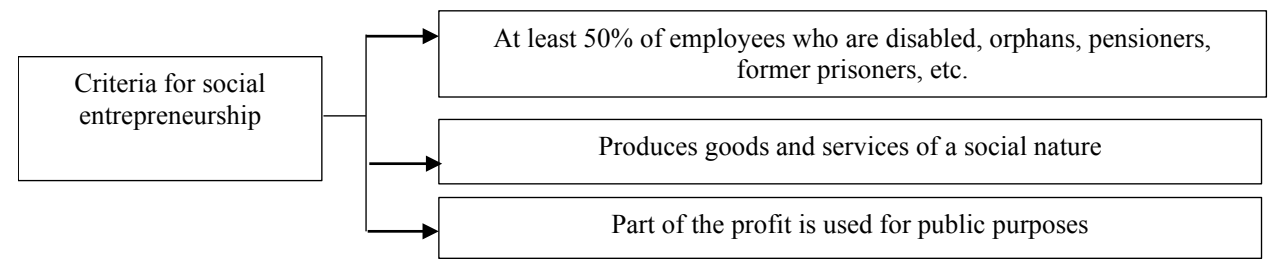

Fig. 2. Criteria for social entrepreneurship.

The state also actively conducts special programs to help start-up entrepreneurs at the level of individual cities and districts. The amount of the subsidy for such programs is from fifty to three hundred thousand rubles. As a rule, these funds are issued to business entities within six months from the date of registration for the purchase of fixed assets or the creation of specialized jobs for the quota categories of employees, minors, and disabled people.

Consider the development of social entrepreneurship in the Lipetsk region based on statistics of rating of the subjects of the Russian Federation on the implementation of mechanisms to support socially oriented non-profit organizations (NGOs) and social entrepreneurship, access, non-governmental organizations to provide social services and implementation of competitive ways of rendering the state (municipal) services in the social sphere.

The first indicator is the number of socially oriented non-profit organizations per 10 thousand people (Table 1).

Place the figure as close as possible after the point where it is first referenced in the text. If there is many figures and tables it might be necessary to place some before their text citation.

Table 1. Number of socially oriented non-profit organizations per 10 thousand population.

\begin{tabular}{|c|c|c|c|}
\hline Indicators & $\mathbf{2 0 1 7}$ & $\mathbf{2 0 1 8}$ & Deviations \\
\hline Number in the rating & 51 & 47 & +4 \\
\hline Characteristics of the subject & $\begin{array}{c}\text { Regions taking the first } \\
\text { steps to success }\end{array}$ & $\begin{array}{c}\text { The regions with } \\
\text { an average level }\end{array}$ & $\uparrow$ \\
\hline The value of the index & 10.1 & 10.2 & +0.1 \\
\hline
\end{tabular}

According to the first indicator, the level of development of social entrepreneurship in the region has increased, because of which the Lipetsk region has moved from regions that are taking the first steps to success to regions with an average level. The second indicator of the assessment is the average share of employees in non-governmental organizations (Table 2).

Table 2. The share of employees in non-governmental organizations in the total number of employees employed in the social sphere, $\%$.

\begin{tabular}{|c|c|c|c|}
\hline Indicators & $\mathbf{2 0 1 7}$ & $\mathbf{2 0 1 8}$ & Deviations \\
\hline Number in the rating & 50 & 21 & +29 \\
\hline $\begin{array}{c}\text { Characteristics of the } \\
\text { subject }\end{array}$ & $\begin{array}{c}\text { The regions with an } \\
\text { average level }\end{array}$ & $\begin{array}{c}\text { Regions, candidates for } \\
\text { leadership }\end{array}$ & $\uparrow$ \\
\hline The value of the index & 4.9 & 8.4 & +3.5 \\
\hline
\end{tabular}

According to Table 2 , the indicator under study grew by $3.5 \%$ in dynamics, which led to a change in the position in the rating. 
Table 3 shows the share of the number of children in private preschool educational organizations.

Table 3. Proportion of the number of children of private preschool educational organizations, $\%$.

\begin{tabular}{|c|c|c|c|}
\hline Indicators & $\mathbf{2 0 1 7}$ & $\mathbf{2 0 1 8}$ & Deviations \\
\hline Number in the rating & 29 & 24 & +5 \\
\hline $\begin{array}{c}\text { Characteristics of the } \\
\text { subject }\end{array}$ & \multicolumn{2}{|c|}{ Regions taking the first steps to success } & - \\
\hline The value of the index & 1.3 & 1.4 & +0.1 \\
\hline
\end{tabular}

In 2018, the share of the number of children of private preschool educational organizations increased by $0.1 \%$, which led to an increase in the rating of the Lipetsk region by 5 points.

The fourth indicator of the rating is the share of municipal districts and urban districts that implement municipal programs to support social-oriented non-profit organizations (Table 4).

Table 4. Percentage of municipal districts and urban districts implementing municipal programs to support social-oriented non-profit organizations, $\%$.

\begin{tabular}{|c|c|c|c|}
\hline Indicators & $\mathbf{2 0 1 7}$ & $\mathbf{2 0 1 8}$ & Deviations \\
\hline Number in the rating & 13 & 15 & -2 \\
\hline Characteristics of the subject & \multicolumn{2}{|c|}{ Regions, candidates for leadership } & - \\
\hline The value of the index & 55 & 75 & +20 \\
\hline
\end{tabular}

Even though the absolute value of the indicator presented in Table 4 increased by $20 \%$, the place in the rating of the Lipetsk region decreased by 2 points.

Table 5 shows the remaining rating indicators, which had a negative trend in 2018 compared to 2017.

Table 5. Factors hindering the development of social entrepreneurship in the Lipetsk region.

\begin{tabular}{|c|c|c|c|}
\hline $\begin{array}{l}\text { Indicators } \\
\end{array}$ & 2017 & 2018 & Deviations \\
\hline \multicolumn{4}{|c|}{$\begin{array}{l}\text { Percentage of municipal districts and urban districts implementing measures to support social } \\
\text { entrepreneurship within the framework of municipal programs to support small and medium- } \\
\text { sized businesses, \% }\end{array}$} \\
\hline Number in the rating & 46 & - & - \\
\hline Characteristics of the subject & $\begin{array}{l}\text { Regions with an } \\
\text { average level }\end{array}$ & - & - \\
\hline The value of the index & 46 & - & - \\
\hline \multicolumn{4}{|c|}{$\begin{array}{l}\text { The share of budget allocations allocated for the provision of subsidies for the implementation } \\
\text { of measures to form the support infrastructure for NGOs, } \%\end{array}$} \\
\hline Number in the rating & 1 & 31 & -30 \\
\hline Characteristics of the subject & Leading regions & $\begin{array}{l}\text { Regions taking the } \\
\text { first steps to success }\end{array}$ & $\downarrow$ \\
\hline The value of the index & 0.0855 & 0.0041 & -0.0814 \\
\hline \multicolumn{4}{|c|}{$\begin{array}{l}\text { The share of non-state (non-municipal) medical organizations participating in the } \\
\text { implementation of the territorial health insurance program, } \%\end{array}$} \\
\hline Number in the rating & 12 & 30 & -18 \\
\hline Characteristics of the subject & Leading regions & $\begin{array}{l}\text { Regions, candidates } \\
\text { for leadership }\end{array}$ & 37,5 \\
\hline The value of the index & 37.62 & 37.5 & -0.12 \\
\hline \multicolumn{4}{|c|}{ The share of non-governmental social service organizations, $\%$} \\
\hline Number in the rating & 31 & 35 & -4 \\
\hline Characteristics of the subject & \multicolumn{2}{|c|}{ Regions with an average level } & - \\
\hline The value of the index & 17.65 & 19.2 & -1.55 \\
\hline
\end{tabular}


Summing up the conducted static analysis, we can conclude that in 2017 the Lipetsk Region was among the leading regions based on the results of the implementation of support mechanisms for socially oriented non-profit organizations and social entrepreneurship. In general, the Lipetsk region ranked sixth in the ranking of the best subjects of the Russian Federation, scoring 32.06 points out of 43 possible [8].

In 2018, according to statistics, the situation worsened, and the Lipetsk region in terms of the development of social entrepreneurship shifted towards the regions with an average level, gaining only 24.65 points. Let us look more specifically at the factors and indicators that hinder the development of social entrepreneurship in the Lipetsk region.

These data indicate that the Lipetsk region was in the leading regions in 2017 by two indicators: the share of budget allocations allocated for the provision of subsidies for the implementation of measures to form the infrastructure for supporting NGOs, as well as the share of non-state (non-municipal) medical organizations participating in the implementation of the territorial program of compulsory health insurance. And on such indicators as for lost income in connection with the use of tax incentives for NGOs from income tax subject of the Russian Federation and the proportion of lost income in connection with the use of tax incentives for supporters of the tax revenue of the subject it in the rankings.

Thus, social entrepreneurship is a promising niche for the development of socially oriented business. It is developing quite dynamically in many regions of the country and is one of the main tools for improving the standard of living of the population and achieving sustainable development in the region.

\section{Conclusion}

As a result of the study, the following results were obtained:

- First, the main characteristics of sustainable development were identified, such as: highquality economic growth, the pace of socio-economic development, lean manufacturing, the introduction of high technologies, ensuring economic security, and social innovations,

- Secondly, the paper clarifies the essence of social innovations in the context of sustainable development and identifies their features (anthropocentrism, strategic nature, inertia, specificity, synergy, creativity, high risk), reflecting their qualitative certainty,

- Third, it was concluded that social innovations are a multi-faceted and rather complex economic category, the content of which should be considered through its types and forms of implementation. On the example of the industrial region (Lipetsk region), such types of social innovations as the social contract and social entrepreneurship were studied,

- Fourthly, the theoretical and practical analysis has led to the understanding that, firstly, the social contract and social entrepreneurship can be considered as two different types of social innovations, and interrelated with each other; secondly, social innovations are an effective tool for improving the level of personal and public well-being by reducing contradictions in society and reducing social tension.

The theoretical and practical significance of this study is to determine the relationship between the sustainable development of an industrial region and social innovations on the example of the social contract and social entrepreneurship.

\section{References}

1. N. Guliyeva, A. Chunikhina, A. Guliyeva, A. Abdulova, Terra Economicus 17(1), 6476 (2019) DOI: 10.23683/2073-6606-2019-17-1-64-76 
2. A. Kisova, Bulletin of the Chelyabinsk State University 11(433), $15-22$ (2019) DOI: 10.24411/1994-2796-2019-11102

3. A. Popov, T. Solovieva, Modern Europe 1, 170-181 (2020) DOI: http://dx.doi.org/10.15211/soveurope 12020170181

4. V.P. Chichkanov, L.A. Belyaevskaya-Plotnik, P.A. Andreeva, Economy of the region 16(1), 1-13 (2020) DOI: 10.17059/2020-1-1

5. G. Duernecker, F. Vega-Redondo, Review of Economic studies 85, 1716-1751 (2018) DOI: $10.1093 /$ restud/rdx054

6. O. Voronkova, L. Iakimova, I. Frolova, Ch. Shafranskaya, S. Kamolov, N. Prodanova, International Journal of Economics and Business Administration 2, 151-163 (2019) DOI: $10.35808 /$ ijeba/223

7. V.V. Okrepilov, S.V. Kuznetsov, S.S. Lachininskii, Studies on Russian Economic Development 31(2), 181-187 (2020). DOI: 10.1134/S1075700720020069

8. D. Pletnev, E. Nikolaeva, E. Silova, E3S Web of Conferences 13014, 210 (2020) doi:10.1051/e3sconf $/ 202021013014$

9. T. Romashchenko, A. Kisova, Proceedings of Voronezh State University. Series: Economics and Management 3, 25-33 (2020) DOI: 10.17308/econ.2020.3/3102.

10. V. Koroleva, Contemporary Problems of Social Work 3-2(10), 146-152 (2017) DOI: 10.17922/2412-5466-2017-3-2-146-152

11. V. Kosarev, P. Pavlov, A. Kaukin, Economic policy 5, 124-149 (2019) DOI: 10.18288/1994-5124-2019-5-124-149

12. Y. Aoyama, B. Parthasarati, Regional development and politics 3, 330-348, (2018) DOI: 10.1080 / 23792949.2018.1481759/

13. M. Malkina, Terra Economicus 18(3), 140-159 (2020) DOI: 10.18522/2073-66062020-18-3-140-159 